\title{
Article \\ Clarifying Soil Texture and Salinity Using Local Spatial Statistics (Getis-Ord Gi* and Moran's I) in Kazakh-Uzbekistan Border Area, Central Asia
}

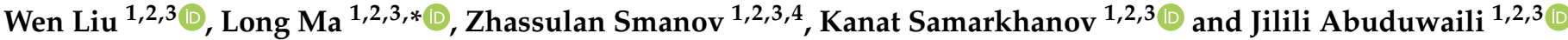 \\ 1 State Key Laboratory of Desert and Oasis Ecology, Xinjiang Institute of Ecology and Geography, \\ Chinese Academy of Sciences, Urumqi 830011, China; liuwen@ms.xjb.ac.cn (W.L.); \\ zhassulan.smanov1307@gmail.com (Z.S.); skgeo@mail.ru (K.S.); jilil@ms.xjb.ac.cn (J.A.) \\ 2 Research Center for Ecology and Environment of Central Asia, Chinese Academy of Sciences, \\ Urumqi 830011, China \\ 3 University of Chinese Academy of Sciences, Beijing 100049, China \\ 4 Kazakh Research Institute of Soil Science and Agrochemistry, Almaty 050060, Kazakhstan \\ * Correspondence: malong@ms.xjb.ac.cn
}

Citation: Liu, W.; Ma, L.; Smanov, Z.; Samarkhanov, K.; Abuduwaili, J. Clarifying Soil Texture and Salinity Using Local Spatial Statistics (Getis-Ord Gi* and Moran's I) in Kazakh-Uzbekistan Border Area, Central Asia. Agronomy 2022, 12, 332. https://doi.org/10.3390/ agronomy12020332

Received: 6 January 2022

Accepted: 27 January 2022

Published: 27 January 2022

Publisher's Note: MDPI stays neutral with regard to jurisdictional claims in published maps and institutional affiliations.

Copyright: (C) 2022 by the authors. Licensee MDPI, Basel, Switzerland. This article is an open access article distributed under the terms and conditions of the Creative Commons Attribution (CC BY) license (https:// creativecommons.org/licenses/by/ $4.0 /)$

\begin{abstract}
The purpose of this paper was to study the spatial characteristics and possible influencing factors of farmland soil texture and salt content in the Syr Darya River Basin. Data on the soil grain size and salt content were collected at 56 sampling sites in the southern part of the Shardara Reservoir and the left bank of the Syr Darya River irrigation area. With the methods of local spatial statistics (Getis-Ord Gi* and Moran's I), the hotspots of soil salinity and grain size in the study area were revealed, and along with the use of correlation analysis, the possible factors affecting soil salt distribution were discussed. Among the 56 soil sampling sites, sandy loam, loamy loam, and chalky loam accounted for $20 \%, 50 \%$, and $30 \%$, respectively, and mildly, moderately, and severely saline soils accounted for $80.36 \%, 14.28 \%$, and $5.36 \%$, respectively. There was statistically significant spatial autocorrelation between sand, silt, and clay content in the soils, but the spatial autocorrelation for salt content was weak. The results show that high and high-cluster areas (hotspots) with statistically significant salt content are mainly distributed in the northwest of the study area and that the hotspot distribution of salt content is mainly affected by topography (altitude), but the effect of soil texture on salt content is not significant. The control of soil salinity should prioritize low-altitude areas, especially in the northwestern region. The results are of great significance for the regulation and control of soil salinity and the sustainable utilization of soil in arid Central Asia.
\end{abstract}

Keywords: soil texture; soil salt; spatial autocorrelation; hotspots; Syr Darya River Basin; Central Asia

\section{Introduction}

Soil is a complex non-homogeneous part of terrestrial ecosystems that not only acts as a hub connecting other environmental elements, but is also a central link between inorganic and biotic combinations, and is formed mainly from soil-forming parent materials through a series of physical, chemical, and biological processes [1,2]. As one of the most important physical properties of soil, soil texture has a significant influence on water-holding capacity, nutrients, erosion, and resistance to wind erosion [3-6]. Existing studies have shown that soil texture has a close relationship with salt content and $\mathrm{pH}$ [7], especially its accumulation and spatial distribution pattern in the surface layer [8]. Increased soil salinity is one of the main factors causing land degradation and desertification, and has become an important factor limiting the ecological environment and efficient agricultural use in arid regions and the productivity of arable land, seriously affecting the status and development of agriculture [9-12]. Therefore, it is of great importance to study the causes, characteristics, and distribution of soil texture, and to carry out integrated planning and comprehensive management of land in certain regions considering local climatic and economic conditions. 
Since the 1960s, the former Soviet Union has been carrying out large-scale agricultural development and construction activities in Central Asia [13]. The use of large volumes of water and the lack of drainage facilities led to widespread salinization of irrigated areas, and secondary salinization of the land has become a serious problem in the region [13]. Victor A. Kovda, who presented the Soil Map of Asia [14,15] and was preoccupied with soil degradation and desertification in the Soviet Union [16,17], is a prominent representative of soil research in Central Asia. The agricultural irrigated arable land of Kazakhstan, a republic of the former Soviet Union, is mainly distributed on both banks of the Syr Darya, one of the major rivers feeding the Aral Sea [18]. While current studies of the soils of the Syr Darya River Basin have mainly focused on the inversion of soil moisture content based on multi-source remotely sensed data [19], the distribution characteristics of heavy metals in the soil $[20,21]$ and assessments by soil conservation services [22] have only found soil salinity mapping with satellite images [23]. Understanding the basic physical characteristics of soil and the spatial distribution of soil salt content is a prerequisite for the rational development and utilization of land resources. However, the texture and salinity characteristics and spatial heterogeneity of agricultural soils in the Syr Darya River Basin of Kazakhstan have not been studied yet.

The spatial characteristics of soil are affected by the superimposed influence of natural weathering and human activities, and the relationship between soil texture and salinity have important significance for agricultural sustainability [24-27]. Kernel density estimation [28-31] and spatial statistics (e.g., semivariogram modeling, Getis-Ord $\mathrm{Gi}^{*}$, $\mathrm{k}$ and Moran's I) [32-38] have mainly been used to accurately evaluate the spatial variability of variables by considering their autocorrelation and randomness factors, and are considered to be the most effective tools for quantifying the spatial distribution of soil physicochemical properties. In this paper, geostatistical methods were used to study the spatial heterogeneity of soil texture and salinity in the Oasis Croplands of the Kazakh-Uzbekistan Border Area, along the Syr Darya River in Kazakhstan, and the results will provide a scientific basis for the rational use and protection of agricultural soils in this region.

\section{Materials and Methods}

\subsection{Sampling and Laboratory Analysis}

The study area covers $1637 \mathrm{~km}^{2}$ including the southern part of the Shardara Reservoir and the left bank of the Syr Darya River irrigation area (Figure 1). The elevation of this study area ranges from 234-282 $\mathrm{m}$ with the SRTM data (https:/ / srtm.csi.cgiar.org/, accessed on 20 August 2021). The distribution of sampling sites (S01-S56) was covered with irrigated croplands (Figure 1), and the sampling depth was $0-20 \mathrm{~cm}$. The detailed locations of the sites are shown in Figure 1 and sampling time was from 10-15 May 2018. The study area has a temperate continental semi-arid climate with a mean annual temperature of $15.5^{\circ} \mathrm{C}$ and annual total rainfall of $338.7 \mathrm{~mm}$ (2020) [39]. According to the classification of soil types by the FAO-UNESCO Soil Map of the World, the study area belongs to the class of Calcic Xerosols [40].

Soil samples were tested for grain size using the classical pipette method, which is the standard method often used in soil science [41-46]. Gravel (>2 mm particle diameter) was screened out from the collected soil, and the composition of soil particles $\leq 2 \mathrm{~mm}$ was measured $[46,47]$. For testing, $10.00 \mathrm{~g}$ of the sample was weighed, three replicates were set up, distilled water and dispersant (sodium hexametaphosphate) were added, and left to soak for $2 \mathrm{~h}$, before it was boiled for $1 \mathrm{~h}$, cooled, and left for $12 \mathrm{~h}$. The sample was passed through a sieve with $0.25 \mathrm{~mm}$ holes into the settling cylinder. Coarse sand larger than $0.25 \mathrm{~mm}$ was trapped in the sieve, washed out, dried, and weighed. For particles smaller than $0.25 \mathrm{~mm}$, the time required for grains to settle to a certain depth was calculated according to Stokes's law. A certain volume of suspension with different grain sizes (fine sand, 0.25-0.05 mm; coarse silt, 0.05-0.01 mm; medium silt, 0.01-0.005 mm; fine silt, $0.005-0.001 \mathrm{~mm}$; and clay smaller than $0.001 \mathrm{~mm}$ ) was sucked up with a pipette at that depth. The aspirated suspension was dried and weighed, and the percent weight content of 
soil particles at each level was calculated. All collected samples were air-dried and extracted and leached at a 5:1 water-to-soil ratio, and the total salt content was determined by the evaporation method after conversion to total soil salt content. The analytical testing of all samples was conducted at the Kazakh Research Institute of Soil Science and Agrochemistry.
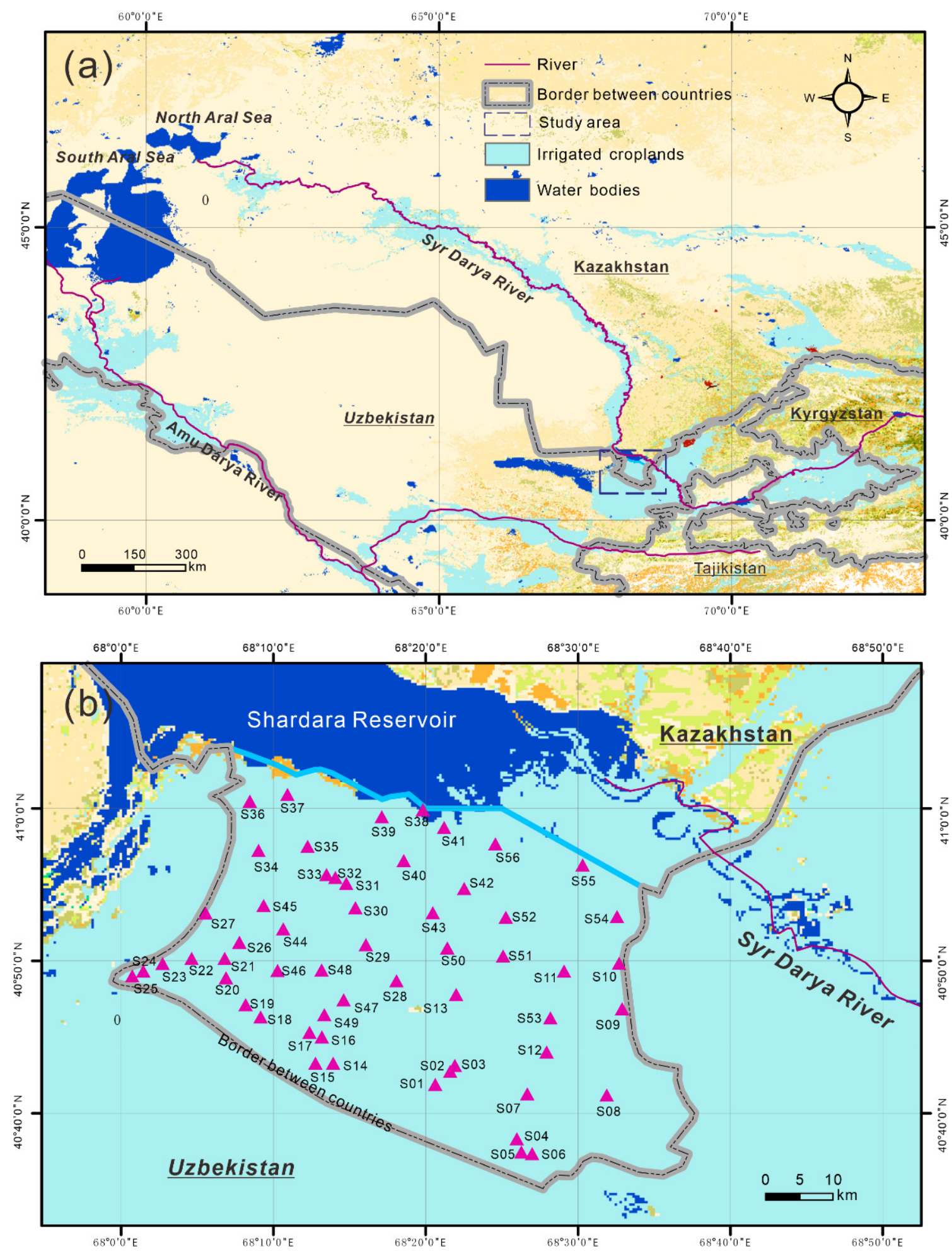

Figure 1. (a) Location of study area in Central Asia; (b) The distribution of sampling sites. 


\subsection{Statistical Analysis}

The local Getis-Ord $G^{*}[36,48-51]$ was used to identify hotspots with statistical significance, and the extremes and hotspots were spatially superimposed to explore the clustering characteristics of the soil and salt distribution in the study area. Moran's I [50,52] was used to detect the spatial autocorrelation of soil grain size and salinity content. These analyses were conducted with GeoDa software [53]. In this study, with GeoDa software, the Queen's Case (contiguity-edges-corners) was chosen as the contiguity conceptualization model to define the spatial relationship among sample sites $[54,55]$. Finally, correlation analysis [56] was performed to determine the correlation relationship between soil grain size composition and salt distribution.

\section{Results}

\subsection{Basic Characteristics of Soil Texture and Soil Salinity}

The mean content of soil particles with grain sizes of fine sand $(0.25-0.05 \mathrm{~mm})$ and coarse silt $(0.05 \mathrm{~m}-0.01 \mathrm{~mm})$ was the largest, and the content of soil particles in these two size ranges accounted for about 31.25 and $32.60 \%$ of the total, respectively (Table 1 ). The average content of medium silt with grain sizes of $0.01-0.005 \mathrm{~mm}$ accounted for only $6.72 \%$, and the content of fine silt with grain sizes of $0.055-0.001 \mathrm{~mm}$ accounted for $10.98 \%$. In addition, the proportion of clay particles in the soil was about $18 \%$. The average content of coarse sand with a grain size of $2-0.25 \mathrm{~mm}$ was the smallest, and its average content was $0.04-1.95 \%$. The raw data from each sampling site can provide a comparative reference for future scientific research, which is of great value; the salt content and soil grain size data for each sampling site in the study area are shown in Figure 2. However, the raw data cannot elucidate the spatial distribution characteristics of soil salinity and soil grain size at sampling sites on a regional scale because there is no correlation coordinate system. According to the USCS and the USDA Soil Classification System [57,58], among the 56 soil sampling sites, sandy loam, loamy loam, and chalky loam accounted for 20,50, and 30\%, respectively (Figure 2 ).

Table 1. Descriptive statistical results of soil environmental parameters in the study area.

\begin{tabular}{ccccccc}
\hline Parameters & Mean & Standard Deviation & SE of Mean & Minimum & Median & Maximum \\
\hline Coarse sand & 0.40 & 0.42 & 0.06 & 0.04 & 0.28 & 1.95 \\
Fine sand & 31.25 & 15.69 & 2.10 & 10.13 & 29.17 & 61.66 \\
Coarse silt & 32.60 & 14.16 & 1.89 & 0.81 & 34.76 & 55.51 \\
Medium silt & 6.72 & 3.57 & 0.48 & 0.00 & 6.04 & 15.74 \\
Fine silt & 10.98 & 2.23 & 0.30 & 11.29 & 17.34 \\
Clay & 18.06 & 1.75 & 0.23 & 10.47 & 18.14 & 20.96 \\
Total salinity & 0.42 & 0.35 & 0.05 & 0.13 & 0.28 & 1.90 \\
\hline
\end{tabular}

The mean value of salt content in the study area was $0.42 \mathrm{~g} \mathrm{~kg}^{-1}$, the minimum value was $0.13 \mathrm{~g} \mathrm{~kg}^{-1}$, and the maximum value was $1.90 \mathrm{~g} \mathrm{~kg}^{-1}$ (Figure 3a). According to the degree of soil salinization [59] (non-saline soil: $<1 \mathrm{~g} \mathrm{~kg}^{-1}$; mildly saline soil: 1-6 $\mathrm{g} \mathrm{kg}^{-1}$; moderately saline soil: $6-10 \mathrm{~g} \mathrm{~kg}^{-1}$; severely saline soil: $10-20 \mathrm{~g} \mathrm{~kg}^{-1}$; saline soil: $>20 \mathrm{~g} \mathrm{~kg}^{-1}$ ), a preliminary evaluation of the degree of salinization in the study area can be made. Based on the analysis results, the soils at the 56 sampling sites showed varying degrees of salinization, with mildly, moderately, and severely saline soils accounting for $80.36,14.28$, and $5.36 \%$ of the total samples, respectively (Figure $3 b$ ).

\subsection{Spatial Autocorrelation and Hotspot Analysis}

From the spatial autocorrelation analysis with the Moran's I (Table 2), the content of sand and silt fractions in the soil showed a strong correlation at the $99 \%$ confidence level $(p<0.01, z>2.58)$, and the clay fraction showed strong spatial autocorrelation at the $95 \%$ confidence level $(p<0.05, z>1.96)$. Based on the hotspot analysis, there were obvious hotspots in the salt content and soil texture in this area: in the 56 soil sampling areas, for 
salinity, there were seven hotspots and six cold spots; for the soil sand component content, there were eight hotspots and three cold spots (Figure 4); for the silty component content, there were five hotspots and eight cold spots; and for the clay component, there were three hotspots and six cold spots. The cold and hotspot areas of the sandy component content was the opposite to that of the silty component.

Table 2. Moran's I and its statistical significance level.

\begin{tabular}{cccc}
\hline Variable & Moran's I & $p$ & $z$ \\
\hline Total salt content & 0.0434 & 0.199 & 0.78 \\
Sand & 0.196 & 0.01 & 2.7099 \\
Silt & 0.219 & 0.003 & 3.0181 \\
Clay & 0.145 & 0.022 & 2.1311 \\
\hline
\end{tabular}

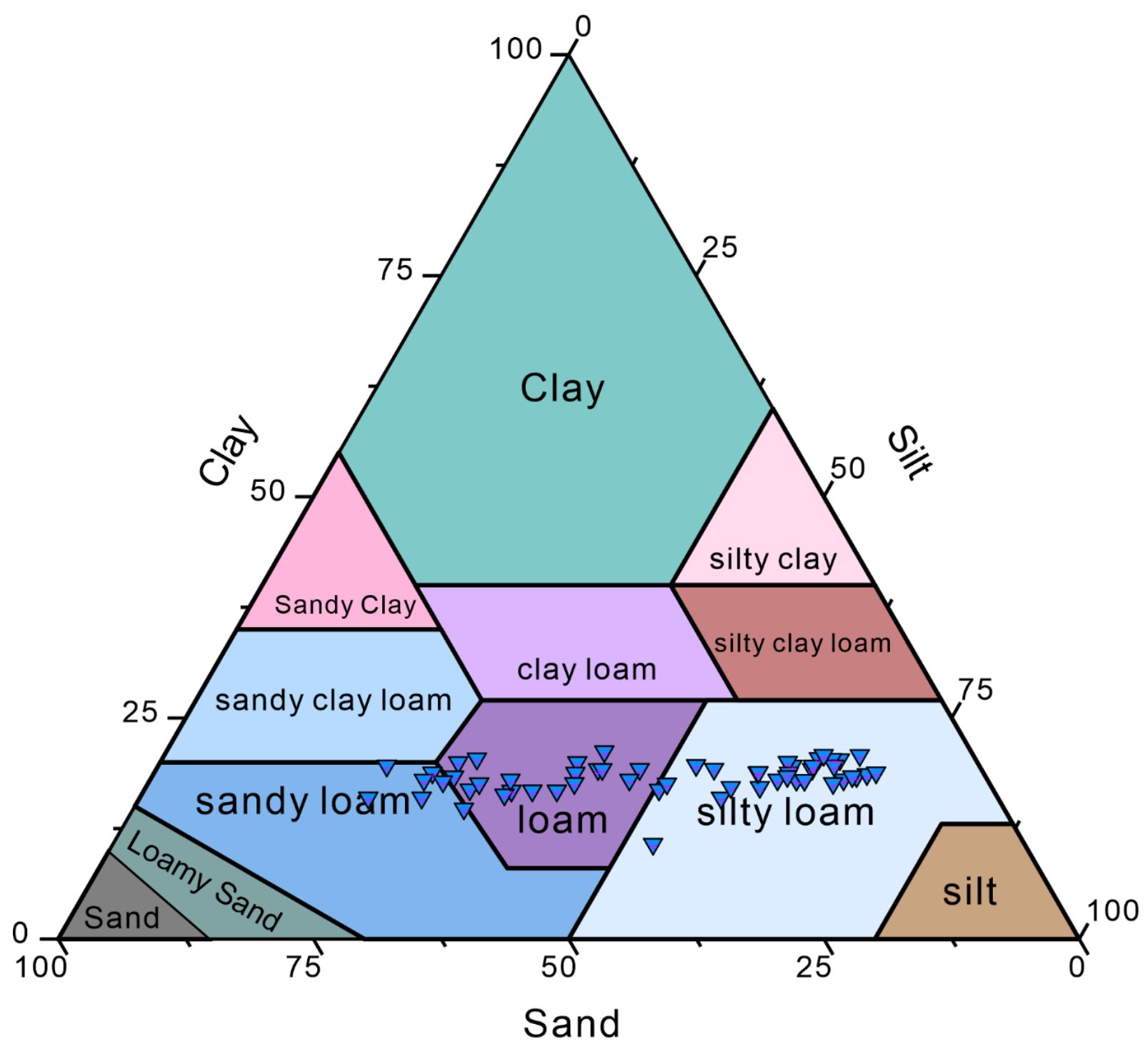

Figure 2. Classifications of soils in sampling sites. Among the 56 soil sampling sites, sandy loam, loamy loam, and chalky loam accounted for 20,50 , and $30 \%$, respectively. 

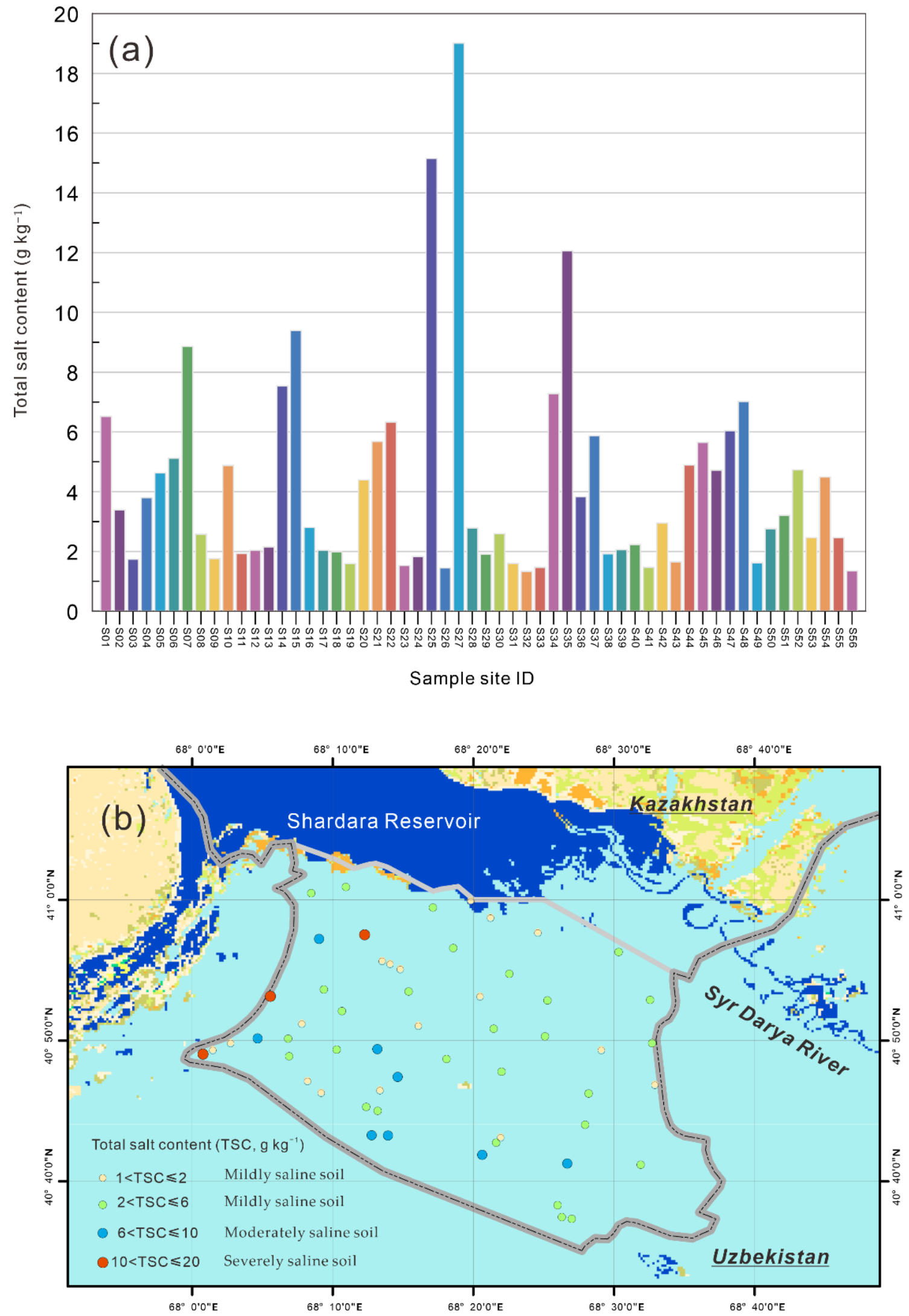

Figure 3. (a) Soil salt content of sample sites; (b) the distribution of saline soils in the study area. 
Hot-spot map with significance for salt content

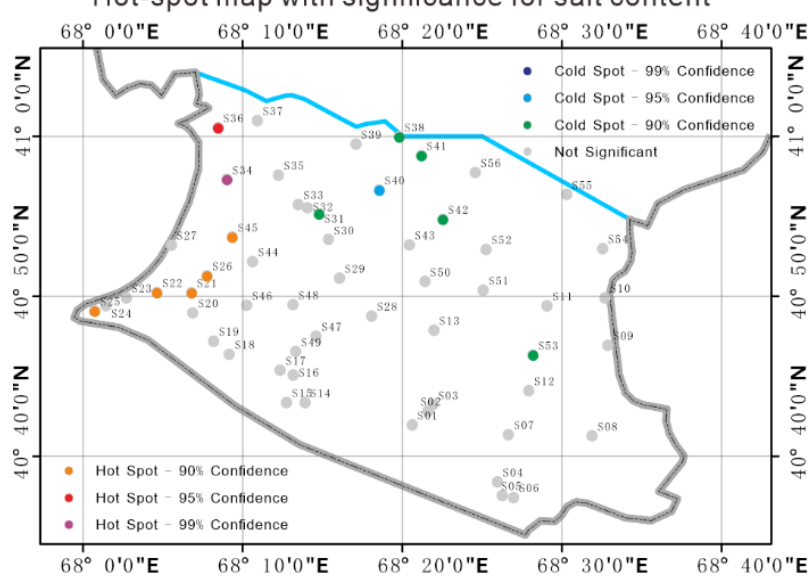

Hot-spot map with significance for slit

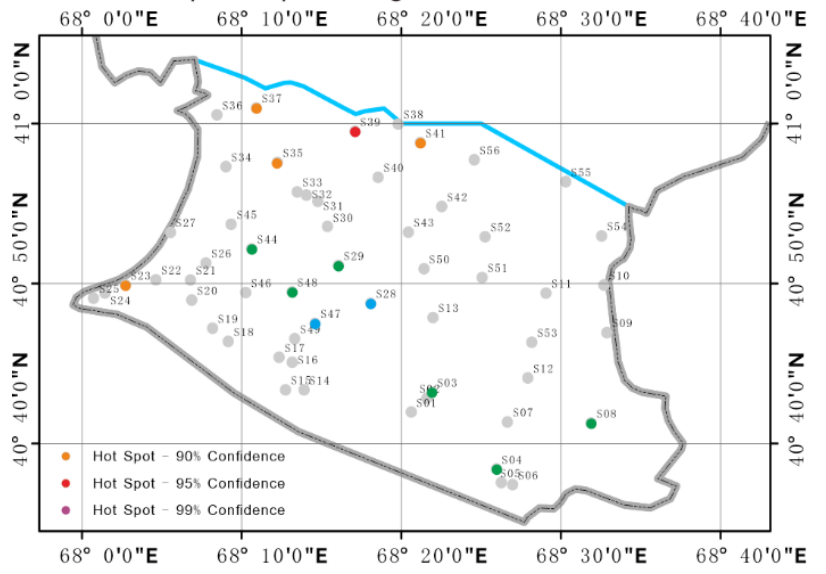

Hot-spot map with significance for sand

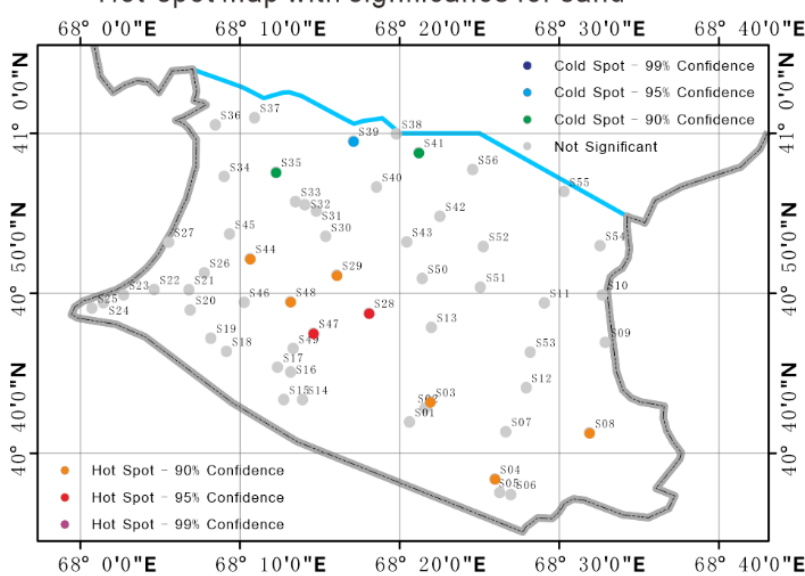

Hot-spot map with significance for clay

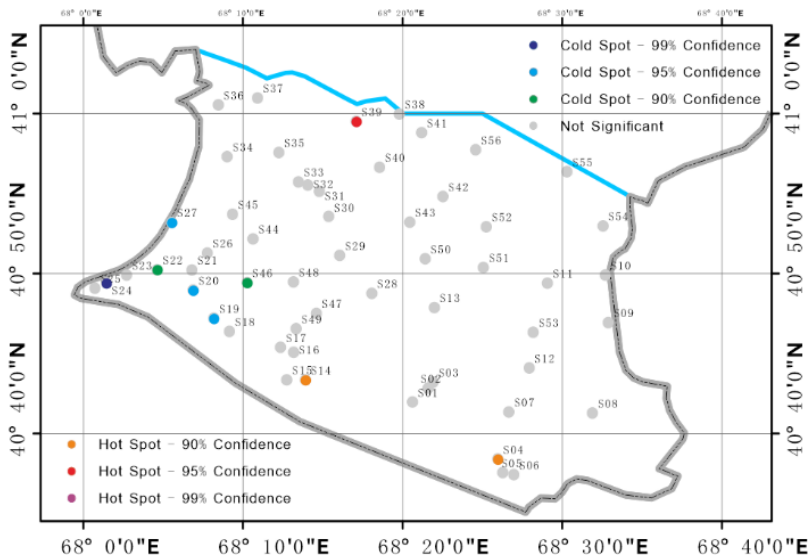

Figure 4. Spatial distribution of hotspots and cold spots in the study area.

\section{Discussion}

Understanding the relationship between soil salinity and soil texture is important for sustainable land use in the arid zone of Central Asia. However, the current research on soil salinity is mainly focused on Xinjiang, China, which is also in the central arid zone [60-62]. Agriculture in Xinjiang is typical oasis agriculture, and the soil salt content is much higher in this region. For example, the salt content of the oasis on the southern slope of Tianshan Mountain in southern Xinjiang is as high as $224.40 \mathrm{~g} / \mathrm{kg}$ [63]. The highest soil salinity in the oasis on the northern margin of the Gurbantunggut Desert in northern Xinjiang is $62.4 \mathrm{~g} / \mathrm{kg}$ [64]. Although the two regions are both arid areas, there are big differences in climate, soil texture, topography, irrigation methods, and farming methods, which will cause great differences in the intensity of soil salinization.

Studying the accumulation mechanism of salt under different economic development levels and farming modes is also one of the directions of future research. In small-scale research, with the same farming conditions and the same climate and geological background, existing studies have shown that soil texture is closely related to soil salt content and has a significant impact on the accumulation and distribution of salt in the surface layer [8]. However, we did not find this phenomenon in this study area (Figure 5), indicating that the accumulation of salt in this area may be affected by other factors. The negative correlation between soil salt content and altitude (Figure 6) shows that the relationship between the two is close. The gently flattened lowlands are areas of salt accumulation, and because a smaller slope leads to slower runoff drainage, large areas of saline soils often form in areas with shallow groundwater burial depths. The topography influences the redistribution of soil-forming materials and hydrothermal conditions. The current analysis shows that 
topography accounts for a large part of the salt accumulation process in the region, explaining 37.9 of total variance (Figure 6). Therefore, the future management of salinity in the region should focus on low-elevation areas, especially the northern areas (where high-high clustering hotspots have formed). Human activities also have a large impact on the spatial variability of soils, and land use practices and irrigation and fertilization measures can cause the spatial variability of soil properties $[65,66]$. Therefore, future research should investigate how human activities alter soil salt accumulation.

The results of hotspot analysis have guiding significance for salinization control. When formulating and implementing relevant prevention and control policies, first, hotspots can be targeted, and then the process can be extended to the whole region to improve the efficiency of salinization prevention and control.

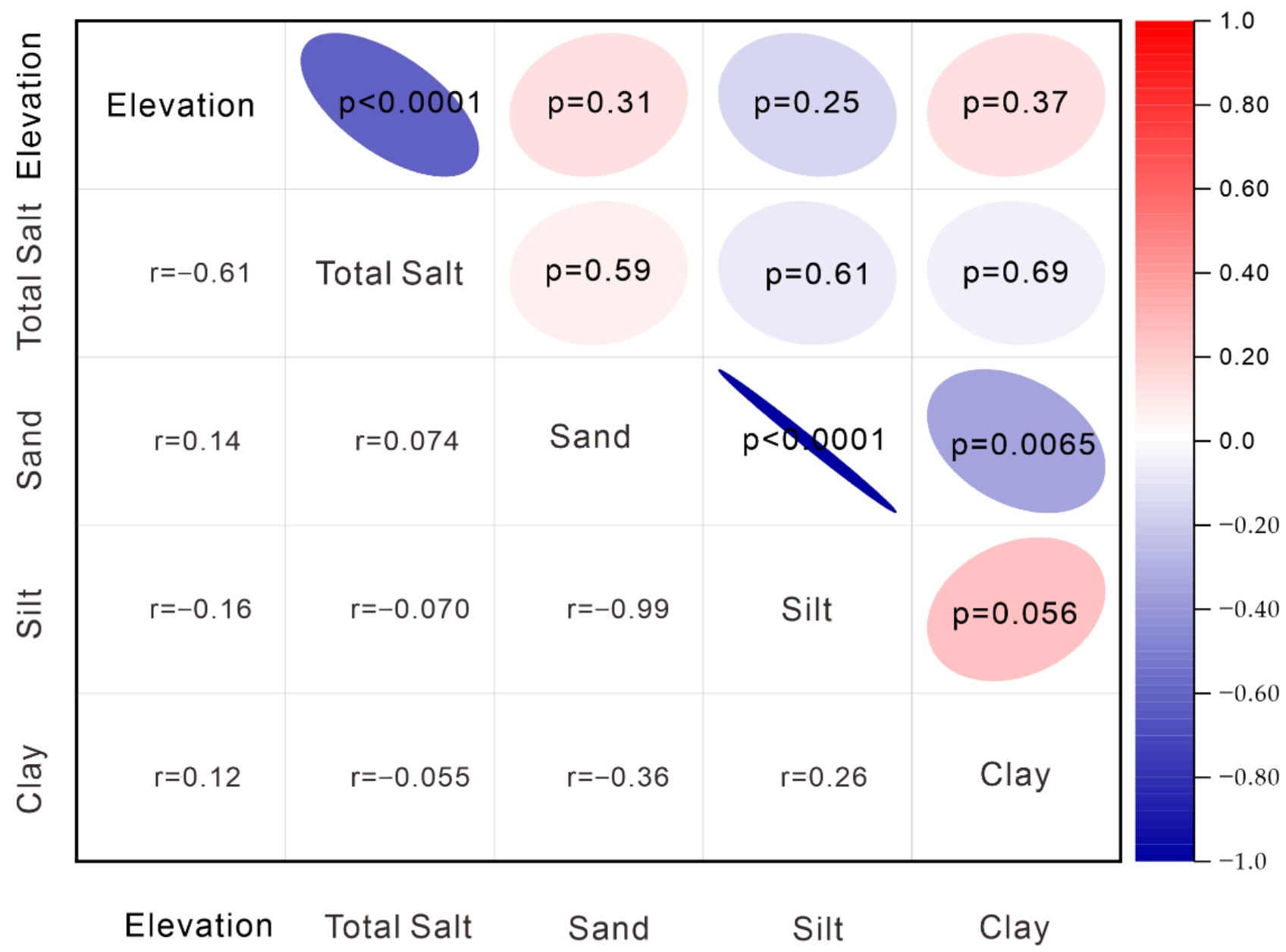

Figure 5. Correlation between soil salt content, altitude, and soil texture. 

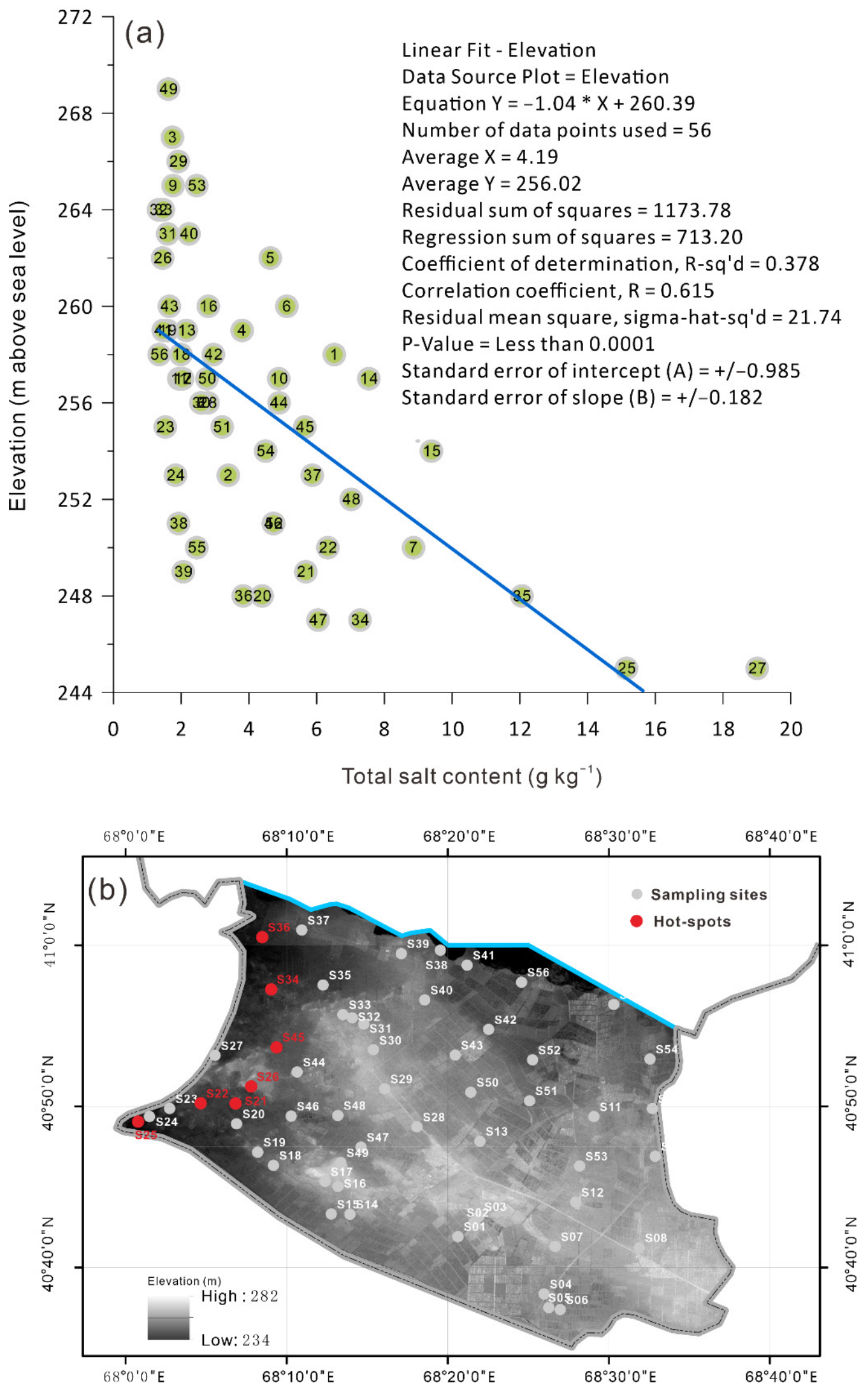

Figure 6. Negative correlation between soil salt content and altitude (a) and the hot-spots of soil salinity distributed in an elevation map (b). The elevation information was collected from the SRTM data (https:/ / srtm.csi.cgiar.org/srtmdata/, accessed on 20 August 2021). 
Spatial data interpolation can effectively estimate the attribute values of unsampled areas. Inverse distance interpolation can effectively estimate the attribute values of unsampled areas with Tobler's first law of geography [67], and is widely used in the study of the spatial distribution characteristics of variables [68-70]. Although the hotspots of salt aggregation were located in the northwestern part of the study area, which is also the low elevation part of the study area (Figure $6 b$ ), some areas with higher salt content were also found in the southern and southwestern part of the study area (Figure 7), which is partly related to the ease of salt accumulation in soils at low elevations (Figure 6a) and partly related to the possible differences in irrigation and drainage practices [71-73]. The latter will require continued attention in future studies. The spatial patterns of soil grain size and salinity in the study area is identified in Figure 7; however, any method of spatial data interpolation is based on pre-conditions of spatial autocorrelation. That is, the reliability of the results depends directly on the existence of spatial autocorrelation with spatial variables. In this study, the spatial autocorrelation of salt content in the study area at the landscape scale (kilometers) was poor, thus it can be said that there was no spatial autocorrelation at the level of statistical significance. Therefore, the soil environmental parameter data obtained by spatial interpolation are less reliable for soil salinity, but they have a higher reference value for soil texture. The sampling scale affects the spatial variability of soil properties, and the degree of autocorrelation of variables in the same landscape can vary considerably at different scales [74,75]. As the scale increases, the forms of variation in soil properties tend to become more complex, and it is possible that their homogeneity at a small scale is an important cause of their variability at large scale [76,77]. Future studies should focus on spatial autocorrelation ranging from the micro level (millimeters) to the plot level (meters).
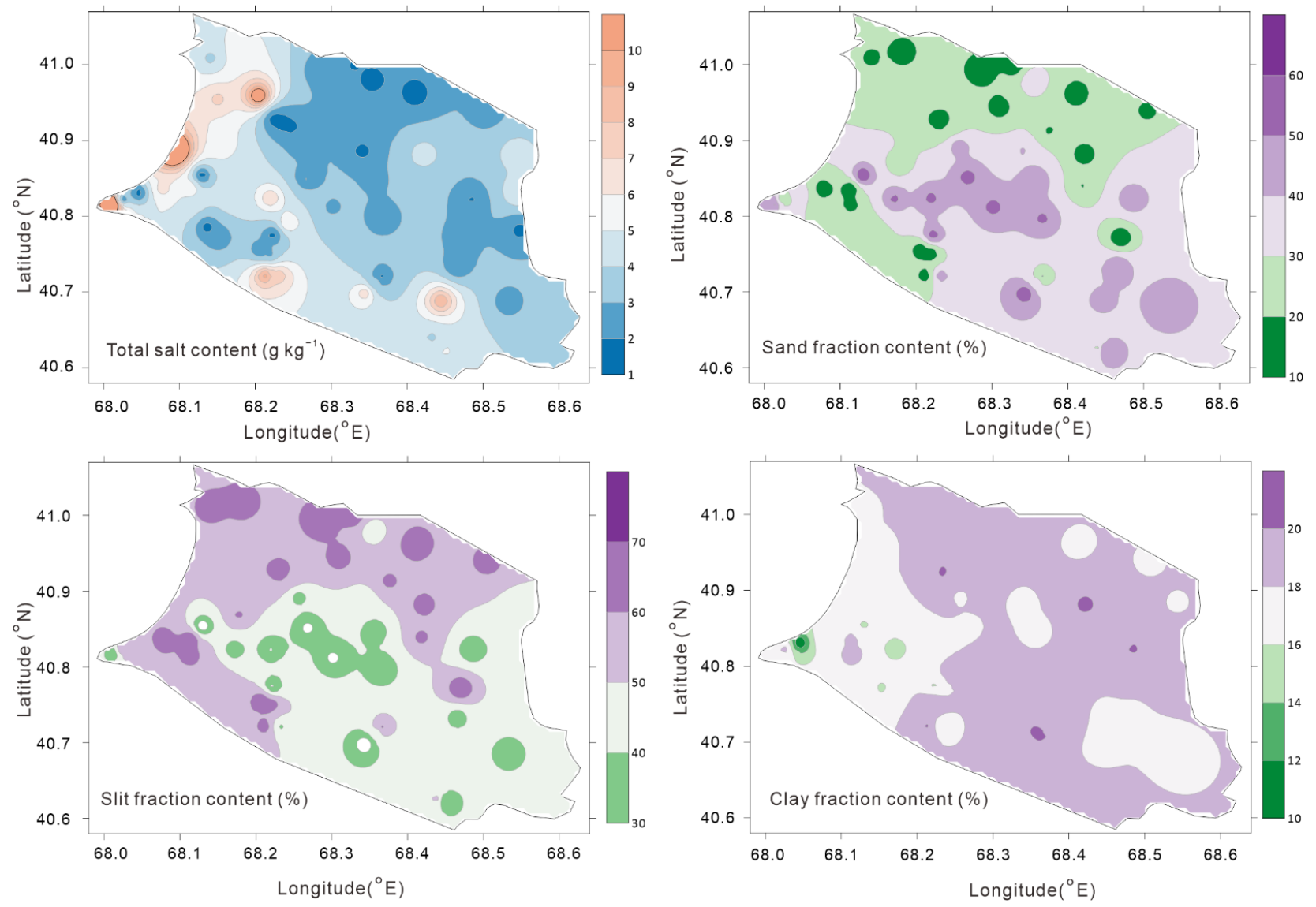

Figure 7. Spatial part of soil grain size and salinity in the study area. 
It should be observed that predicting the potential development of salinization is critical for the study region's long-term sustainability. This research focuses on the spatial characteristics and influencing factors of soil texture and salinity, which are utilized as a reference for land management departments and have significant reference value for sustainable agriculture. However, due to the study's data limitations in creating a prediction model $[78,79]$, we cannot provide a picture of future changes in soil salinization in this study. In future research, we will study the origin of salt through the composition of salt chemical ions, and will also build a model to examine the future development trend of soil salinization in the context of human activities and climate change. Future study will provide solid technological support for regional sustainable development.

\section{Conclusions}

Analyzing the spatial characteristics of soil texture and soil salinity and demonstrating their relationship and influencing factors have important basic research value for land use and protection in arid regions of Central Asia. The soil in the study area basically belongs to the category of loam; at the same time, it has been affected by salinization to varying degrees. Moderately salinized soil accounted for nearly $20 \%$ of the total samples. Spatial statistical analysis showed a statistically significant spatial autocorrelation for soil grain size composition, but the spatial autocorrelation for soil salt content was not significant. Hotspot analysis showed that high and high-cluster areas (hotspots) with statistically significant salt content are mainly distributed in the northwest of the study area and that the hotspot distribution of salt content is mainly affected by topography (altitude), but the effect of soil texture on salt content is not significant.

Author Contributions: Formal analysis, W.L.; Funding acquisition, L.M.; Investigation, L.M., Z.S. and K.S.; Methodology, W.L., L.M. and J.A.; Supervision, L.M. and J.A.; Writing-original draft, W.L., Z.S. and K.S.; Writing-review \& editing, L.M. and J.A. All authors have read and agreed to the published version of the manuscript.

Funding: This research was funded by the Regional Collaborative Innovation Project of Xinjiang Uygur Autonomous Region of China (2020E01013); the LU JIAXI International team program supported by the K.C. Wong Education Foundation (GJTD-2020-14), and the High-Level Training Project of Xinjiang Institute of Ecology and Geography, Chinese Academy of Sciences (E050030101).

Institutional Review Board Statement: Not applicable.

Data Availability Statement: Not applicable.

Acknowledgments: We thank the two anonymous reviewers for their valuable comments and suggestions.

Conflicts of Interest: The authors declare no conflict of interest.

\section{References}

1. Amundson, R.; Berhe, A.A.; Hopmans, J.W.; Olson, C.; Sztein, A.E.; Sparks, D.L. Soil and human security in the 21st century. Science 2015, 348, 1261071. [CrossRef] [PubMed]

2. Huang, P.M.; Wang, S.-L.; Tzou, Y.-M.; Huang, Y.; Weng, B.; Zhuang, S.; Wang, M.K. Physicochemical and biological interfacial interactions: Impacts on soil ecosystem and biodiversity. Environ. Earth Sci. 2013, 68, 2199-2209. [CrossRef]

3. Arshad, M.; Coen, G. Characterization of soil quality: Physical and chemical criteria. Am. J. Altern. Agric. 1992, 7, 25-31. [CrossRef]

4. Zhao, H.; Cui, J.; Zhou, R.; Zhang, T.; Zhao, X.; Drake, S. Soil properties, crop productivity and irrigation effects on five croplands of Inner Mongolia. Soil Tillage Res. 2007, 93, 346-355. [CrossRef]

5. Pierce, F.; Lal, R. Monitoring the impact of soil erosion on crop productivity. In Soil Erosion Research Methods; Routledge: Boca Raton, FL, USA, 2017; pp. 235-263.

6. Hevia, G.G.; Buschiazzo, D.E.; Hepper, E.N.; Urioste, A.; Antón, E. Organic matter in size fractions of soils of the semiarid Argentina. Effects of climate, soil texture and management. Geoderma 2003, 116, 265-277. [CrossRef]

7. Pahlavan-Rad, M.R.; Akbarimoghaddam, A. Spatial variability of soil texture fractions and pH in a flood plain (case study from eastern Iran). Catena 2018, 160, 275-281. [CrossRef] 
8. Hu, H.; Tian, F.; Hu, H. Soil particle size distribution and its relationship with soil water and salt under mulched drip irrigation in Xinjiang of China. Sci. China-Technol. Sci. 2011, 54, 1568-1574. [CrossRef]

9. Qadir, M.; Noble, A.D.; Schubert, S.; Thomas, R.J.; Arslan, A. Sodicity-induced land degradation and its sustainable management: Problems and prospects. Land Degrad. Dev. 2006, 17, 661-676. [CrossRef]

10. Shahid, S.A.; Zaman, M.; Heng, L. Soil salinity: Historical perspectives and a world overview of the problem. In Guideline for Salinity Assessment, Mitigation and Adaptation Using Nuclear and Related Techniques; Springer Nature Switzerland AG: Cham, Switzerland, 2018; pp. 43-53.

11. Metternicht, G.I.; Zinck, J. Remote sensing of soil salinity: Potentials and constraints. Remote Sens. Environ. 2003, 85, 1-20. [CrossRef]

12. Daliakopoulos, I.; Tsanis, I.; Koutroulis, A.; Kourgialas, N.; Varouchakis, A.; Karatzas, G.; Ritsema, C. The threat of soil salinity: A European scale review. Sci. Total Environ. 2016, 573, 727-739. [CrossRef]

13. Smedema, L.K.; Shiati, K. Irrigation and salinity: A perspective review of the salinity hazards of irrigation development in the arid zone. Irrig. Drain. Syst. 2002, 16, 161-174. [CrossRef]

14. Selcer, P. 4. The Soil Map Of The World And The Politics Of Scale. In The Postwar Origins of the Global Environment; Columbia University Press: New York, NY, USA, 2018; pp. 133-172.

15. Selcer, P. Fabricating unity: The FAO-UNESCO soil map of the world. Hist. Soc. Res. 2015, 40, $174-201$.

16. Rispoli, G.; Olšáková, D. Science and Diplomacy around the Earth: From the Man and Biosphere Programme to the International Geosphere-Biosphere Programme. Hist. Stud. Nat. Sci. 2020, 50, 456-481. [CrossRef]

17. Kovda, V.A. The Earth's living matter: Biosphere and soils. Environ. Conserv. 1993, 20, 199-204. [CrossRef]

18. Jia, Q.; Li, Y.; Li, Y.; Huang, G. Analyzing variation of inflow from the Syr Darya to the Aral Sea: A Bayesian-neural-network-based factorial analysis method. J. Hydrol. 2020, 587, 124976. [CrossRef]

19. Wang, H.; Luo, G.; Wang, W.; Konstantin, P.; Li, Y.; Zheng, H.; Hu, W. Inversion of soil moisture content in the farmland in middle and lower reaches of Syr Darya River Basin based on multi-source remotely sensed data. J. Nat. Resour. 2019, 34, $2717-2731$.

20. Ma, L.; Abuduwaili, J.; Smanov, Z.; Ge, Y.; Samarkhanov, K.; Saparov, G.; Issanova, G. Spatial and Vertical Variations and Heavy Metal Enrichments in Irrigated Soils of the Syr Darya River Watershed, Aral Sea Basin, Kazakhstan. Int. J. Environ. Res. Public Health 2019, 16, 4398. [CrossRef]

21. Solodukhin, V.; Poznyak, V.; Kazachevskiy, I.; Knyazev, B.; Lukashenko, S.; Khazhekber, S. Some peculiarities of the contamination with radionuclides and toxic elements of the Syrdarya river basin, Kazakhstan. J. Radioanal. Nucl. Chem. 2004, 259, 245-250. [CrossRef]

22. Ma, X.; Zhu, J.; Yan, W.; Zhao, C. Assessment of soil conservation services of four river basins in Central Asia under global warming scenarios. Geoderma 2020, 375, 114533. [CrossRef]

23. Platonov, A.; Noble, A.; Kuziev, R. Soil Salinity Mapping Using Multi-Temporal Satellite Images in Agricultural Fields of Syrdarya Province of Uzbekistan. In Developments in Soil Salinity Assessment and Reclamation: Innovative Thinking and Use of Marginal Soil and Water Resources in Irrigated Agriculture; Shahid, S.A., Abdelfattah, M.A., Taha, F.K., Eds.; Springer: Dordrecht, The Netherlands, 2013; pp. 87-98.

24. AbdelRahman, M.A.; Zakarya, Y.M.; Metwaly, M.M.; Koubouris, G. Deciphering Soil Spatial Variability through Geostatistics and Interpolation Techniques. Sustainability 2021, 13, 194. [CrossRef]

25. Wang, Z.; Zhang, F.; Zhang, X.; Chan, N.W.; Kung, H.-t.; Zhou, X.; Wang, Y. Quantitative evaluation of spatial and temporal variation of soil salinization risk using GIS-based geostatistical method. Remote Sens. 2020, 12, 2405. [CrossRef]

26. Wang, Z.; Chen, X.; Yu, D.; Zhang, L.; Wang, J.; Lv, J. Source apportionment and spatial distribution of potentially toxic elements in soils: A new exploration on receptor and geostatistical models. Sci. Total Environ. 2021, 759, 143428. [CrossRef] [PubMed]

27. Jin, Z.; Zhang, L.; Lv, J.; Sun, X. The application of geostatistical analysis and receptor model for the spatial distribution and sources of potentially toxic elements in soils. Environ. Geochem. Health 2021, 43, 407-421. [CrossRef] [PubMed]

28. Lin, Y.-P.; Chu, H.-J.; Wu, C.-F.; Chang, T.-K.; Chen, C.-Y. Hotspot Analysis of Spatial Environmental Pollutants Using Kernel Density Estimation and Geostatistical Techniques. Int. J. Environ. Res. Public Health 2011, 8, 75-88. [CrossRef]

29. Hu, Y.; Wang, F.; Guin, C.; Zhu, H. A spatio-temporal kernel density estimation framework for predictive crime hotspot mapping and evaluation. Appl. Geogr. 2018, 99, 89-97. [CrossRef]

30. Spencer, C.J.; Yakymchuk, C.; Ghaznavi, M. Visualising data distributions with kernel density estimation and reduced chi-squared statistic. Geosci. Front. 2017, 8, 1247-1252. [CrossRef]

31. Wang, D.; Li, M. Robust stochastic configuration networks with kernel density estimation for uncertain data regression. Inf. Sci. 2017, 412, 210-222. [CrossRef]

32. Goovaerts, P. Geostatistical modelling of uncertainty in soil science. Geoderma 2001, 103, 3-26. [CrossRef]

33. Linnik, V.G.; Bauer, T.V.; Minkina, T.M.; Mandzhieva, S.S.; Mazarji, M. Spatial distribution of heavy metals in soils of the flood plain of the Seversky Donets River (Russia) based on geostatistical methods. Environ. Geochem. Health 2020. online. [CrossRef]

34. Jurišić, M.; Radočaj, D.; Krčmar, S.; Plaščak, I.; Gašparović, M. Geostatistical analysis of soil C/N deficiency and its effect on agricultural land management of major crops in eastern Croatia. Agronomy 2020, 10, 1996. [CrossRef]

35. Xia, F.; Hu, B.; Zhu, Y.; Ji, W.; Chen, S.; Xu, D.; Shi, Z. Improved Mapping of Potentially Toxic Elements in Soil via Integration of Multiple Data Sources and Various Geostatistical Methods. Remote Sens. 2020, 12, 3775. [CrossRef] 
36. Lee, S.; Na, S.; Rogers, O.G.; Youn, S. Quantifying surface morphology of manufactured activated carbon and the waste coffee grounds using the Getis-Ord-Gi* statistic and Ripley's K function. Sci. Rep. 2021, 11, 7543. [CrossRef] [PubMed]

37. Olea, R.A. A six-step practical approach to semivariogram modeling. Stoch. Environ. Res. Risk Assess. 2006, 20, 307-318. [CrossRef]

38. Koike, K.; Kiriyama, T.; Lu, L.; Kubo, T.; Heriawan, M.N.; Yamada, R. Incorporation of geological constraints and semivariogram scaling law into geostatistical modeling of metal contents in hydrothermal deposits for improved accuracy. J. Geochem. Explor. 2022, 233, 106901. [CrossRef]

39. Harris, I.; Osborn, T.J.; Jones, P.; Lister, D. Version 4 of the CRU TS monthly high-resolution gridded multivariate climate dataset. Sci. Data 2020, 7, 109. [CrossRef] [PubMed]

40. Nachtergaele, F.; van Velthuizen, H.; Verelst, L.; Batjes, N.; Dijkshoorn, K.; van Engelen, V.; Fischer, G.; Jones, A.; Montanarela, L. The harmonized world soil database. In Proceedings of the 19th World Congress of Soil Science, Soil Solutions for a Changing World, Brisbane, Australia, 1-6 August 2010; pp. 34-37.

41. Beuselinck, L.; Govers, G.; Poesen, J.; Degraer, G.; Froyen, L. Grain-size analysis by laser diffractometry: Comparison with the sieve-pipette method. Catena 1998, 32, 193-208. [CrossRef]

42. Igaz, D.; Aydin, E.; Šinkovičová, M.; Šimanský, V.; Tall, A.; Horák, J. Laser diffraction as an innovative alternative to standard pipette method for determination of soil texture classes in Central Europe. Water 2020, 12, 1232. [CrossRef]

43. Arriaga, F.J.; Lowery, B.; Mays, M.D. A fast method for determining soil particle size distribution using a laser instrument. Soil Sci. 2006, 171, 663-674. [CrossRef]

44. Liu, J.; Hu, F.; Xu, C.; Wang, Z.; Ma, R.; Zhao, S.; Liu, G. Comparison of different methods for assessing effects of soil interparticle forces on aggregate stability. Geoderma 2021, 385, 114834. [CrossRef]

45. Thomas, C.L.; Hernandez-Allica, J.; Dunham, S.J.; McGrath, S.P.; Haefele, S.M. A comparison of soil texture measurements using mid-infrared spectroscopy (MIRS) and laser diffraction analysis (LDA) in diverse soils. Sci. Rep. 2021, 11, 1-12.

46. Peng, Y.; Keating, K.; Myers, D.B. NMR relaxation times for soil texture estimation in the laboratory: A comparison to the laser diffraction and sieve-pipette methods. Eur. J. Soil Sci. 2021, 72, 918-933. [CrossRef]

47. Qi, F.; Zhang, R.; Liu, X.; Niu, Y.; Zhang, H.; Li, H.; Li, J.; Wang, B.; Zhang, G. Soil particle size distribution characteristics of different land-use types in the Funiu mountainous region. Soil Tillage Res. 2018, 184, 45-51. [CrossRef]

48. Feng, Y.; Chen, X.; Gao, F.; Liu, Y. Impacts of changing scale on Getis-Ord Gi* hotspots of CPUE: A case study of the neon flying squid (Ommastrephes bartramii) in the northwest Pacific Ocean. Acta Oceanolog. Sin. 2018, 37, 67-76. [CrossRef]

49. Kumar, S.; Parida, B.R. Hydroponic farming hotspot analysis using the Getis-Ord Gi* statistic and high-resolution satellite data of Majuli Island, India. Remote Sens. Lett. 2021, 12, 408-418. [CrossRef]

50. Ren, H.; Shang, Y.; Zhang, S. Measuring the spatiotemporal variations of vegetation net primary productivity in Inner Mongolia using spatial autocorrelation. Ecol. Indic. 2020, 112, 106108. [CrossRef]

51. Al-Kindi, K.M.; Alkharusi, A.; Alshukaili, D.; Al Nasiri, N.; Al-Awadhi, T.; Charabi, Y.; El Kenawy, A.M. Spatiotemporal assessment of COVID-19 spread over Oman using GIS techniques. Earth Syst. Environ. 2020, 4, 797-811. [CrossRef]

52. Hu, X.; Ma, C.; Huang, P.; Guo, X. Ecological vulnerability assessment based on AHP-PSR method and analysis of its single parameter sensitivity and spatial autocorrelation for ecological protection-A case of Weifang City, China. Ecol. Indic. 2021, 125, 107464. [CrossRef]

53. Anselin, L.; Syabri, I.; Kho, Y. GeoDa: An introduction to spatial data analysis. In Handbook of Applied Spatial Analysis; Springer: Berlin/Heidelberg, Germany, 2010; pp. 73-89.

54. Lin, M.; Lin, T.; Jones, L.; Liu, X.; Xing, L.; Sui, J.; Zhang, J.; Ye, H.; Liu, Y.; Zhang, G. Quantitatively assessing ecological stress of urbanization on natural ecosystems by using a landscape-adjacency index. Remote Sens. 2021, 13, 1352. [CrossRef]

55. Pezzulo, C.; Nilsen, K.; Carioli, A.; Tejedor-Garavito, N.; Hanspal, S.E.; Hilber, T.; James, W.H.; Ruktanonchai, C.W.; Alegana, V.; Sorichetta, A. Geographical distribution of fertility rates in 70 low-income, lower-middle-income, and upper-middle-income countries, 2010-2016: A subnational analysis of cross-sectional surveys. Lancet Glob. Health 2021, 9, e802-e812. [CrossRef]

56. Makowski, D.; Ben-Shachar, M.S.; Patil, I.; Lüdecke, D. Methods and algorithms for correlation analysis in R. J. Open Source Soft. 2020, 5, 2306. [CrossRef]

57. García-Gaines, R.A.; Frankenstein, S. USCS and the USDA Soil Classification System: Development of a Mapping Scheme; U.S. Army Engineer Research and Development Center: Vicksburg, MS, USA, 2015.

58. Groenendyk, D.G.; Ferré, T.P.A.; Thorp, K.R.; Rice, A.K. Hydrologic-Process-Based Soil Texture Classifications for Improved Visualization of Landscape Function. PLoS ONE 2015, 10, e0131299. [CrossRef] [PubMed]

59. Wang, Z.; Zhang, X.; Zhang, F.; Chan, N.w.; Kung, H.-t.; Liu, S.; Deng, L. Estimation of soil salt content using machine learning techniques based on remote-sensing fractional derivatives, a case study in the Ebinur Lake Wetland National Nature Reserve, Northwest China. Ecol. Indic. 2020, 119, 106869. [CrossRef]

60. Zhang, W.-T.; Wu, H.-Q.; Gu, H.-B.; Feng, G.-L.; Wang, Z.; Sheng, J.-D. Variability of Soil Salinity at Multiple Spatio-Temporal Scales and the Related Driving Factors in the Oasis Areas of Xinjiang, China. Pedosphere 2014, 24, 753-762. [CrossRef]

61. Wang, F.; Chen, X.; Luo, G.; Han, Q. Mapping of regional soil salinities in Xinjiang and strategies for amelioration and management. Chin. Geogr. Sci. 2015, 25, 321-336. [CrossRef]

62. Abuduwaili, J.; Tang, Y.; Abulimiti, M.; Liu, D.; Ma, L. Spatial distribution of soil moisture, salinity and organic matter in Manas River watershed, Xinjiang, China. J. Arid Land 2012, 4, 441-449. [CrossRef] 
63. Jiang, H.; Shu, H. Optical remote-sensing data based research on detecting soil salinity at different depth in an arid-area oasis, Xinjiang, China. Earth Sci. Inf. 2019, 12, 43-56. [CrossRef]

64. Wang, Y.; Xiao, D.; Li, Y.; Li, X. Soil salinity evolution and its relationship with dynamics of groundwater in the oasis of inland river basins: Case study from the Fubei region of Xinjiang Province, China. Environ. Monit. Assess. 2008, 140, 291-302. [CrossRef]

65. Fu, C.; Gan, S.; Yuan, X.; Xiong, H.; Tian, A. Determination of soil salt content using a probability neural network model based on particle swarm optimization in areas affected and non-affected by human activities. Remote Sens. 2018, 10, 1387. [CrossRef]

66. Huang, J.; Hartemink, A.E. Soil and environmental issues in sandy soils. Earth-Sci. Rev. 2020, 208, 103295. [CrossRef]

67. Tobler, W.R. A computer movie simulating urban growth in the Detroit region. Econ. Geogr. 1970, 46, 234-240. [CrossRef]

68. Shukla, K.; Kumar, P.; Mann, G.S.; Khare, M. Mapping spatial distribution of particulate matter using Kriging and Inverse Distance Weighting at supersites of megacity Delhi. Sust. Cities Soc. 2020, 54, 101997. [CrossRef]

69. Chen, F.-W.; Liu, C.-W. Estimation of the spatial rainfall distribution using inverse distance weighting (IDW) in the middle of Taiwan. Paddy Water Environ. 2012, 10, 209-222. [CrossRef]

70. Shen, Q.; Wang, Y.; Wang, X.; Liu, X.; Zhang, X.; Zhang, S. Comparing interpolation methods to predict soil total phosphorus in the Mollisol area of Northeast China. Catena 2019, 174, 59-72. [CrossRef]

71. Schultz, B.; De Wrachien, D. Irrigation and drainage systems research and development in the 21st century. Irrig. Drain. 2002, 51, 311-327. [CrossRef]

72. Machado, R.M.A.; Serralheiro, R.P. Soil Salinity: Effect on Vegetable Crop Growth. Management Practices to Prevent and Mitigate Soil Salinization. Horticulturae 2017, 3, 30. [CrossRef]

73. Rhoades, J.D.; Lesch, S.M.; LeMert, R.D.; Alves, W.J. Assessing irrigation/drainage/salinity management using spatially referenced salinity measurements. Agric. Water Manag. 1997, 35, 147-165. [CrossRef]

74. Cobo, J.G.; Dercon, G.; Yekeye, T.; Chapungu, L.; Kadzere, C.; Murwira, A.; Delve, R.; Cadisch, G. Integration of mid-infrared spectroscopy and geostatistics in the assessment of soil spatial variability at landscape level. Geoderma 2010, 158, 398-411. [CrossRef]

75. Wang, Y.; Zhang, X.; Huang, C. Spatial variability of soil total nitrogen and soil total phosphorus under different land uses in a small watershed on the Loess Plateau, China. Geoderma 2009, 150, 141-149. [CrossRef]

76. Dobermann, A. Factors causing field variation of direct-seeded flooded rice. Geoderma 1994, 62, 125-150. [CrossRef]

77. Garten, C.T.; Kang, S.; Brice, D.J.; Schadt, C.W.; Zhou, J. Variability in soil properties at different spatial scales $(1 \mathrm{~m}-1 \mathrm{~km})$ in a deciduous forest ecosystem. Soil Biol. Biochem. 2007, 39, 2621-2627. [CrossRef]

78. Wang, F.; Shi, Z.; Biswas, A.; Yang, S.; Ding, J. Multi-algorithm comparison for predicting soil salinity. Geoderma 2020, $365,114211$. [CrossRef]

79. Hassani, A.; Azapagic, A.; Shokri, N. Predicting long-term dynamics of soil salinity and sodicity on a global scale. Proc. Natl. Acad. Sci. USA 2020, 117, 33017-33027. [CrossRef] [PubMed] 